http://dx.doi.org/10.11646/zoosymposia.14.1.16

http://zoobank.org/urn:lsid:zoobank.org:pub:9A7EE643-1BFD-405C-900E-2FFC9B2A9ADE

\title{
The Trichoptera (Insecta) of the lower Kunene River in Namibia and Angola
}

\author{
WOLFRAM MEY ${ }^{1} \&$ FERDINAND C. DE MOOR ${ }^{2}$ \\ ${ }^{1}$ Leibniz Institut für Evolutions- und Biodiversitätsforschung Museum für Naturkunde an der Humboldt-Universität Berlin \\ Invalidenstraße 43D - 10115 Berlin \\ e-mail: wolfram.mey@mfn-berlin.de \\ ${ }^{2}$ Department of Freshwater Invertebrates, Albany Museum, and Department of Zoology and Entomology, Rhodes University, \\ Grahamstown 6139, South Africa \\ e-mail:F.deMoor@ru.ac.za
}

\begin{abstract}
The Trichoptera of the lower Kunene River were collected at irregular intervals from 1994 to 2012 by the first author. Samples were taken mainly at several localities on the Namibian side of the border downstream of the Ruacana hydroelectric power plant. Field work concentrated on adults, which were collected by light traps. Together with results of previous investigations a total of 41 species in 16 genera covering five families are now recorded from the river. About four species were found as immatures in the past, and were identified to generic level only. The first author has collected 27 species including nine undescribed ones: Catoxyethira kunenica sp. nov., Orthotrichia epupae sp. nov., O. vadalis sp. nov., O. kunenensis sp. nov., Ecnomus magnus sp. nov., E. quadrangulatus sp. nov., E. (Psychomyiellodes) statzneri sp. nov., E. (Psychomyiellodes) angonamus sp. nov. and Ceraclea (Pseudoleptocerus) lepidopterella sp. nov. Descriptions and illustrations of the genitalia of the new species are provided. Two species were synonymized: Oecetis kunenensis Barnard, $1934=$ Oectis reticulatella Kimmins, 1957, syn. nov. and Oecetis tripunctata (Fabricius, 1793) = Oecetis ovamboensis Barnard, 1934, syn. nov.
\end{abstract}

Key words: Trichoptera, faunistics, taxonomy, new species descriptions, Kunene River, Namibia, Angola

\section{Introduction}

Knowledge about the biodiversity of freshwater invertebrates is crucial in detecting and foreseeing the consequences of human impact and/or natural changes in these ecosystems. This knowledge is of particular importance in arid regions where freshwater is a limited and yet rapidly changing resource and, as a result, is strongly affected by the socio-economic conditions of the country. Namibia and southern Angola are in one of the world's most arid regions with few perennial wetlands, which are under strong human pressure. This results in rapid ecosystem changes and fragmentation of these freshwater ecosystems.

A dozen major rivers and smaller streams traverse the Namib Desert and coastal Succulent Karoo from east to west. Most of them are ephemeral watercourses carrying water only briefly after heavy and long lasting rainfall (Harrison 1997). Only two are permanent rivers with drainages entering the South Atlantic Ocean: Kunene River in the north (borderline between Angola and Namibia), Fig. 1.

Orange River in the south (borderline between Namibia and South Africa). Both rivers are ancient, desert streams in their lower courses with all the ecological peculiarities of this type of running water (Kingsford 2006).

The Orange River is a comparatively well researched river and comprehensive information was provided by Cambray et al. (1986), de Moor and Car (1986), Earle et al. (2005), Giller and Malmquist (1998), Harrison (1997), Hogan (2013), and Palmer (1996). Due to its remote position on the periphery of Namibia and Angola, the Kunene River is much less researched (cf. Hogan 2012). 


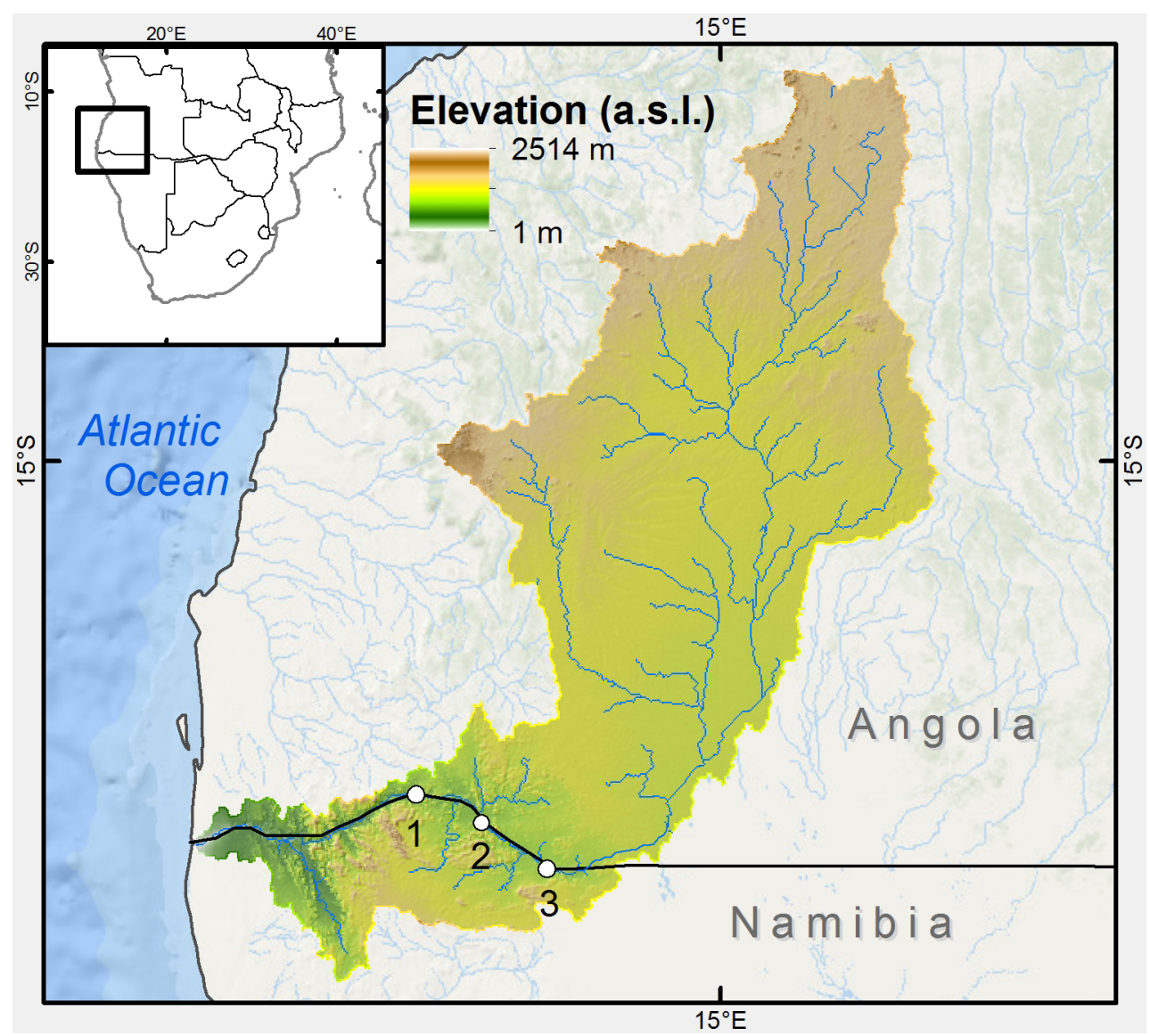

FIGURE 1. Watershed of the Kunene River and location of the principal collecting sites on the lower course of the river (1-Epupa Falls, 2-Swartbooisdrif, 3-Ruacana, camp site).

There are plans to construct new hydroelectric power stations in the lower and upper courses of the Kunene (Simmons et al. 1993, de Moor et al. 2000, Hogan 2012). This construction will further affect the environmental conditions under which the aquatic fauna has developed. The endemic elements of the river will especially become endangered by a changing water regime. Endemic species are known to occur in the fish fauna, with five of the 69 species recognised to date (Hay et al. 1997). The presence of these species points to the existence of further freshwater endemic species in groups, which have not been studied to date, or are insufficiently sampled. The Trichoptera belong to these under-sampled groups, and the question arises whether or not the caddisfly assemblages contribute to the unique biodiversity of the river by adding further endemic species.

The Trichoptera are still imperfectly researched in Namibia. Curtis (1991) compiled a first checklist containing 32 species. Research on the fauna of the Okavango, Kwando and Zambezi has raised the number to over 80 (Mey 2001). The species of dams and lakes in the interior of Namibia have remained unstudied. Barnard (1998) reported three species of Trichoptera as Namibian endemics, however, without mentioning the names of the species and their distribution. A number of springs along the escarpment were sampled in recent years and their study revealed the existence of a small fauna encompassing about 10 species (Mey 2016). The caddisflies of the Orange River were summarised and analysed by Mey (2011). The fauna of the lower section of this large river is rather poor with 26 species recorded so far. One species, Catoxyethira gariepensis Mey, 2011, was described from a series of adult specimens. As it is geographically isolated with the closest congeners occurring in the Kunene and Okavango Rivers, nearly $2000 \mathrm{~km}$ away, this is possibly a species endemic to the Orange River.

The Kunene and the Okavango-Zambezi systems share about 70 species of fish, confirming ancient links between these systems mediated by the Etosha Pan. The Pan was a lake fed by the Kunene River before the drainage system changed and the Kunene River diverted westwards to the Atlantic about 35, 000 years ago (Barnard 1998). 
Probably the first workers who collected caddisflies on the banks of the Kunene River were K. H. Barnard and R. F. Lawrence in 1923. A total of seven new species were described from their material (Barnard 1934). In 1997 and 1998 the invertebrate fauna of the river, including caddisflies, was investigated again and the results were published by de Moor et al. (2000). Together with records from previous studies, a total of 251 species covering all aquatic insect orders were recorded for the Kunene River in Namibia. Caddisflies belong to the more species-rich groups and a total of 30 taxa were recorded from these two surveys. Of the species identified 12 were regarded as undescribed species. An additional five species were found only as immatures, and were identified to generic level only. The present paper mainly aims at clarifying the taxonomy of most of the encountered species and to describe the undescribed ones.

\section{Material and methods}

The first author has visited the Kunene River three times in different seasons (2000, 2008 and 2012). Field work was undertaken at a number of localities on the Namibian side downstream from the Ruacana power scheme. The power scheme is situated close to locality 3 in Fig. 1. The main collecting sites were:

1. Epupa Falls, $17^{\circ} 00^{\prime} 24^{\prime \prime S} 13^{\circ} 14^{\prime} 52$ 'E, $704 \mathrm{~m}$ asl, (Fig. 2),

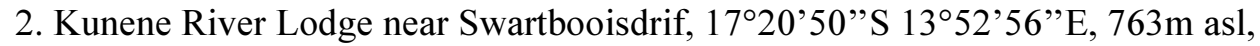

3. Campsite near Ruacana, close to the river, $17^{\circ} 24^{\prime} 27^{\prime}$ 'S $14^{\circ} 13^{\prime} 05^{\prime \prime} \mathrm{E}, 925 \mathrm{~m}$ asl.

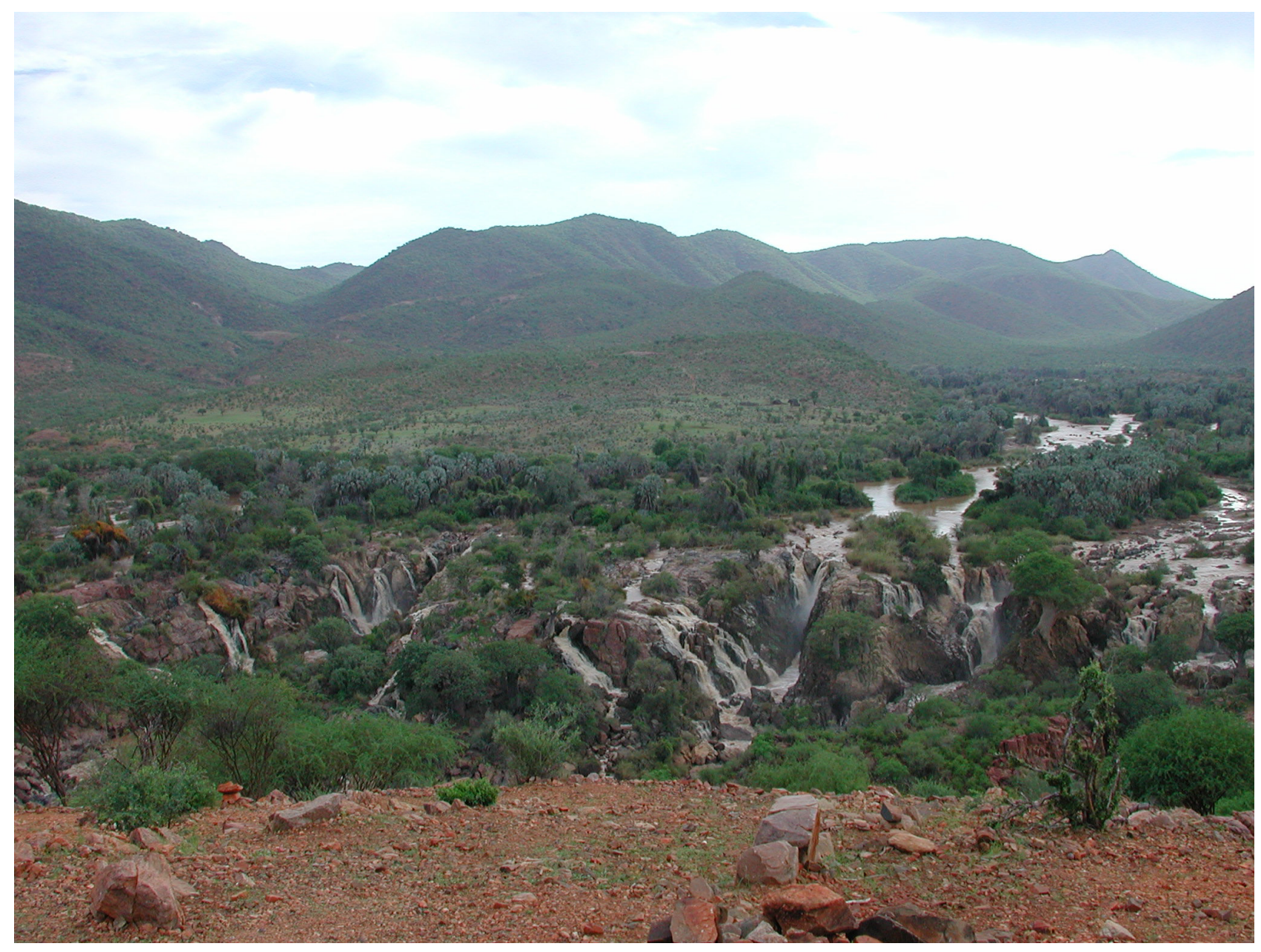

FIGURE 2. Epupa Falls on the Kunene River, photographed from SW. The mountains in the background are in Angola. 
The Kunene watershed and the collecting sites on the lower course are indicated in Fig. 1. Systematic sampling in the upper sections of the river in Angola was always an option but did not happen after the civil war because local cooperation partners were unavailable at that time. Additional material was donated by entomologist-colleagues of the Museum für Naturkunde, Berlin during their field work in the Kaokoveld of Namibia and in Angola (see Acknowledgements). The material, collected by the second author, was available for inclusion in this study and collecting methods were described by de Moor et al. (2000). Sketches of the male genitalia of nearly all species were available in the Albany Museum. The illustrations were detailed enough to associate most of the species recorded as undescribed in the 1997 and 1998 surveys with the species collected by the first author.

The majority of Trichoptera species reported in the present study were collected at lights. Usually, a lighttower (with two $12 \mathrm{~W}$ superactinic fluorescent tubes) was placed in the vicinity of the river, and the arriving insects were picked up from the gauze sheet that surrounds the tubes. In addition, a HWL lamp (160 W) hanging in front of a white sheet and powered by a generator (Honda EX 7) was deployed at a second site in the valley before the falls. Collecting started at sunset and continued for 3-4 hours. The material was partly collected in alcohol $(75 \%)$ and partly preserved dry. The dry collected specimens were pinned and micropinned the next day.

The material is deposited in the following museums:

AMG-Albany Museum, Grahamstown, South Africa

MfN-Museum für Naturkunde, Berlin, Germany

NMNW-National Museum of Namibia, Windhoek

\section{Results and discussions}

In Table 1 all 41 species hitherto recorded from the lower Kunene River are summarised. During three collecting campaigns the first author has collected about 1100 specimens in 27 species including nine undescribed ones (Table 2). According to de Moor et al. (2000) there were 12 undescribed species collected during that study. From these, four species which were given identification labels under the catalogue entries KUN1 A-KUN158 of the AMG (Hydroptila sp. KUN64F, Catoxyethira sp. KUN1L, Orthotrichia sp. KUN $118 \mathrm{M}$ and Oecetis sp. KUN32Q) were not found again in material collected by the first author. These species are, however, included in the compiled inventory and will be described by the authors at a later date.

TABLE 1. Synopsis of Trichoptera species recorded along the lower Kunene River by various researchers.

\begin{tabular}{|c|c|c|c|}
\hline Species & CURTIS (1991) & $\begin{array}{c}\text { DE MOOR et al. } \\
(\mathbf{2 0 0 0 )}\end{array}$ & leg. W. MEY \\
\hline \multicolumn{4}{|l|}{ Hydroptilidae } \\
\hline Hydroptila cruciata Ulmer, 1912 & & o & o \\
\hline Hydroptila spec. 1 (KUN64F) & & o & \\
\hline Hydroptila spec. 2 (larvae) & & o & \\
\hline Orthotrichia petiti Jacquemart, 1962 & & o & \\
\hline Orthotrichia epupae spec. nov. & & o & o \\
\hline Orthotrichia vadalis spec. nov. & & o & o \\
\hline Orthotrichia kunenensis spec. nov & & o & o \\
\hline Orthotrichia spec. 3 (KUN118M) & & o & \\
\hline Orthotrichia spec. 4 (larvae) & & o & \\
\hline Catoxyethira veruta Morse, 1974 & & o & o \\
\hline Catoxyethira kunenica spec. nov. & & o & o \\
\hline Catoxyethira spec. 2 (KUN1L) & & o & \\
\hline
\end{tabular}


TABLE 1. (Continued)

$\begin{array}{lccc}\text { Species } & \text { CURTIS (1991) } & \begin{array}{c}\text { DE MOOR et al. } \\ (2000)\end{array} & \text { leg. W. MEY }\end{array}$

Ecnomidae

Ecnomus barnardi Scott, 1963

Ecnomus kunenensis Barnard, 1934

o

Ecnomus thomasseti Mosely, 1932

o

o

Ecnomus complex Mosely, 1932

Ecnomus quadrangulatus spec. nov.

$=E$. similis Mosely, 1932, sensu de Moor

Ecnomus ulmeri Mosely, 1932

Ecnomus spec. 2 (larvae)

Ecnomus (Psychomyiellodes) angonamus spec. nov.

Ecnomus (Psychomyiellodes) statzneri spec. nov.

\section{Dipseudopsidae}

Dipseudopsis capensis Walker, 1852

Dipseudopsis simplex Ulmer, 1905

\section{Hydropsychidae}

Amphipsyche maxima Ulmer, 1906

o

Amphipsyche senegalensis (Brauer, 1875)

Aethaloptera dispar (Brauer, 1875)

Cheumatopsyche thomasseti Ulmer, 1931

\section{Leptoceridae}

Athripsodes fissus (Ulmer, 1912)

= Ceraclea spec., sensu de Moor

Homilia vetulata Barnard, 1934

= Athripsodes spec., sensu de Moor

Oecetis rama Mosely, 1948

Oecetis kunenensis Barnard, 1934

$=O$. reticulatella Kimmins, 1957, syn. nov.

Oecetis tripunctata (Fabricius, 1793)

Oecetis spec. 2 (KUN32Q)

Parasetodes maguirus (Mosely, 1948)

o

Trichosetodes anysa Mosely, 1948

Leptocerus didymatus Barnard, 1934

= Leptocerus intricatus (Mosely, 1939) sensu de Moor

Triaenodes siculus (Barnard, 1934). 
Some species were recorded by de Moor et al. (2000) on the basis of immatures only. Overlapping identifications of larvae and adults cannot be ruled out, and some of the published names are probably based on misidentifications that cannot be corrected currently (e. g. Aethaloptera maxima). However, there are likely going to be additional undescribed species not yet recorded that will need to be described. The first author knows of at least one Hydropsyche species present in the upper sections of the Kunene River but not found in the lower section to date. There is probably a balance between new species descriptions and reductions in numbers due to taxonomic changes.

The composition of the Trichoptera community of the lower Kunene River is rather similar to that of the lower Orange River at the family level. With only five families and 16 genera present, the taxonomic diversity of the lower Kunene River seems to be quite reduced. Though the Kunene River has 15 species more in its lower course than the Orange River, the fauna cannot be termed rich and diverse. The impression of a poor taxocenosis is mainly based on the absence of the families Philopotamidae, Polycentropodidae, Psychomyidae, and the presence of only a few representatives of Hydropsychidae. Almost certainly, further sampling activities will increase the total number of species. We have no data from the winter months (April to August), and we expect that at least some species are on the wing in this season too. But most if not all of the new findings will probably belong to rare species or species with low abundances.

TABLE 2. List of Trichoptera species and number of specimens collected by W. Mey and associated collectors along the lower Kunene River (1994-2015) (new species shaded grey)

\begin{tabular}{lcc}
\hline Species & $\begin{array}{c}\text { leg. W. MEY } \\
\text { J/q }\end{array}$ & relative abundance \\
\hline Hydroptilidae & & 0,02 \\
Hydroptila cruciata Ulmer, 1912 & $14 / 9$ & 0,058 \\
Orthotrichia epupae spec. nov. & $31 / 37$ & 0.023 \\
Orthotrichia vadalis spec. nov. & $17 / 10$ & 0,0008 \\
Orthotrichia kunenensis spec. nov. & $1 / 0$ & 0,014 \\
Catoxyethira veruta Morse, 1974 & $5 / 11$ & 0,0017 \\
Catoxyethira kunenica spec. nov. & $2 / 0$ &
\end{tabular}

\section{Ecnomidae}

Ecnomus barnardi Scott, 1963

$17 / 0 \quad 0,015$

Ecnomus magnus spec. nov.

$12 / 2$

Ecnomus quadrangulatus spec. nov.

Ecnomus (Psychomyiellodes) angonamus spec. nov.

\section{Dipseudopsidae}

Dipseudopsis capensis Walker, 1852

\section{Hydropsychidae}

Aethaloptera dispar Brauer, 1875

$41 / 15 \quad 0,048$

Amphipsyche senegalensis (Brauer, 1875) 
TABLE 2. (Continued)

\begin{tabular}{|c|c|c|}
\hline Species & $\begin{array}{c}\text { leg. W. MEY } \\
\delta / q\end{array}$ & relative abundance \\
\hline \multicolumn{3}{|l|}{ Leptoceridae } \\
\hline Ceraclea (Pseudoleptocerus) lepidopterella spec. nov. & $32 / 22$ & 0,045 \\
\hline Ceracldea (Pseudoleptocerus) cuprea Barnard, 1934 & $3 / 0$ & 0,0025 \\
\hline Homilia vetulata Barnard, 1934 & $3 / 2$ & 0,0043 \\
\hline Oecetis kunenensis Barnard, 1934 & $21 / 22$ & \\
\hline$=O$. reticulatella Kimmins, 1957, syn nov. & & 0,037 \\
\hline Oecetis rama Mosely, 1948 & $13 / 8$ & 0,018 \\
\hline Oecetis tripunctata (Fabricius, 1793) & $49 / 24$ & \\
\hline$=$ O. ovamboensis Barnard, 1934, syn. nov. & & 0,063 \\
\hline Parasetodes maguirus (Mosely, 1948) & $24 / 7$ & 0,03 \\
\hline Trichosetodes anysa Mosely, 1948 & $2 / 2$ & 0,003 \\
\hline Leptocerus didymatus Barnard, 1934 & $42 / 28$ & 0,06 \\
\hline Triaenodes siculus Barnard, 1934. & $2 / 0$ & 0,0017 \\
\hline
\end{tabular}

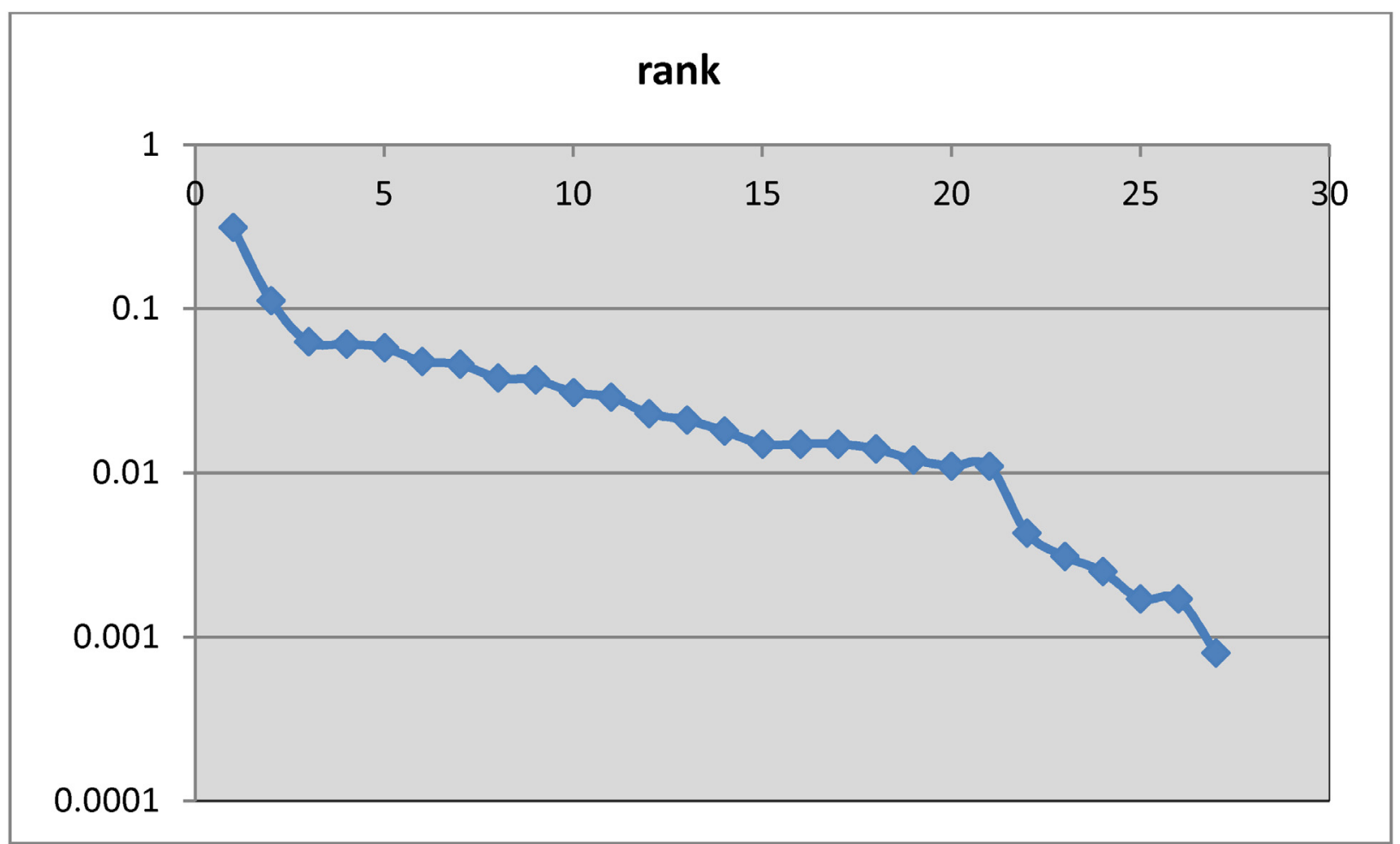

FIGURE 3. Rank/abundance plot of the Trichoptera species collected by W. Mey (see Table 2)

Species represented by singletons and doubletons are only a few, which gives the impression of an adequately and exhaustively sampled taxocenosis. Also, the rank/abundance graph (Fig. 3) shows a good correspondence to a geometric series, a typical feature of small and sufficiently sampled communities (Magguran 2004). The dominant species in all years surveyed by the first author were Cheumatopsyche falcifera (Ulmer, 1930), followed by Ecnomus quadrangulatus sp. nov. and Oecetis tripunctata (Fabricius, 1793). They were collected at all major sampling sites along the Kunene River. Also de Moor et al. (2000) found the former two species to be abundant from the Ruacana Falls up to downstream sites far beyond the 
Epupa Falls. The three most abundant species recorded in these surveys were Cheumatopsyche falcifera followed by Oecetis epupae sp. nov. and Ecnomus quadrangulatus sp. nov. Interestingly, Oecetis tripunctata was not mentioned by de Moor et al. (2000) and this is possibly, because the species has a restricted flight period and adults are not present in large numbers all months of the year. The predatory larvae of Oecetis species were mainly found in riffles along the river (de Moor et al. (2000).

Barnard (1934) described 7 species from the Kunene River, of which Ecnomus kunenensis is the only one not found again. The species has a large distribution in Africa (Tobias 2013) and its absence in all samples taken by the authors is somewhat surprising. The species is either rare or has disappeared completely today. Both explanations would suggest that Ecnomus kunenensis has been affected by the installation and operation of the hydroelectric power plant at Ruacana in 1975-1978. However, we do not know the larvae, their biology and ecological requirements. Without these data we can hardly estimate the effect of the hydroelectric development on this species. One further example of a perhaps negatively influenced species is Ceraclea cuprea Barnard, 1934. Many specimens were collected by Barnard (1934), which is suggestive of an abundant species that time. Only a few specimens were collected by us more than 80 years later. Instead, the congeneric species, Ceraclea lepidopterella sp. nov., was found to be a common insect along the lower section of the Kunene River on the Namibian side and further upstream in Angola. Possibly, it has replaced C. cuprea as a dominant species. Both species can easily be separated externally which allows a quick identification and counting for instance in light trap samples. This renders the species pair a promising candidate for monitoring changes in the population dynamics of aquatic insects in the Kunene. Further studies in Angola, upstream of the Ruacana power scheme, have the potential to discover, in which ways and to what extend the present Trichoptera community in Namibia has changed since the establishment of the hydroelectric power plant in 1975-1978. The available historical data and the data presented herein provide a good basis for future research on the Trichoptera of the Kunene River.

\section{Review of species}

\section{Hydroptilidae}

Catoxyethira kunenica sp. nov.

Holotype đ̊, Namibia, Kunene River, Swartbooisdrif, Kunene River Lodge 17²0’50”S 1352'56”E, 26-28.11.2000, leg. W. Mey, male genitalia slide Mey 13/16 (MfN)

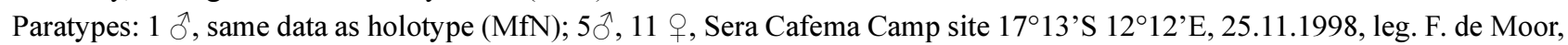
KUN 116G, (AMG).

Etymology: The name refers to the type locality, the Kunene River.

Description. Adult: length of forewing $2.1 \mathrm{~mm}$. Head brown, vertex flat dorsally, median ocellus beneath a short, triangular and acute process on frontal edge; frontoclypeus trapezoid, darker than frons; first segment of maxillary palpi very short, last segment longest of all segments; spurs 1.3.4.

Male genitalia (Figs. 4-6): Sternum of segment VIII with two pairs of long and thick spines on distal margin, anterior margin deeply excised ventrally; segment IX invaginated into segment VIII; inferior appendages and segment IX fused to form a composed plate with short apophyses on base of inferior appendages. Phallic apparatus tubular, slightly curved ventrad and with pointed tip.

Diagnosis: The species belongs to the mali-group of species, whose synapomorphic characters are long spines on unmodified margin of segment VIII, the invaginated tergum IX as well as the inferior appendages. Based on the male genitalia, the new species is similar to Catoxyethira graboensis Gibon, 1985 from West Africa and C. fombani Gibon, 1993 from Camerun. Catoxyethira kunenica sp. nov. differs from these species by the architecture of segments IX and $\mathrm{X}$ and the position of the elongate spines on the ventral and dorsal corner of segment VIII.

Orthotrichia kunenensis sp. nov.

Holotype đે, Namibia, Kunene River, Swartbooisdrif, Kunene River Lodge, 17²0’50”'S 1352'56”E, 26-28.11.2000, leg. W. Mey,male genitalia slide Mey 12/16 (MfN). 
Etymology: The name refers to the type locality, the Kunene River.

Description. Adult: length of forewing $1.5 \mathrm{~mm}$. Head brown, vertex broad and protruding, ocelli absent, maxillary palpi pale yellow, antenna with $24-26$ flagellomeres $(n=2)$. Forewings brown, without white spots or stripes, underside of costal vein with a short row of black, androconial scales. Venter of segments VI and VII with median process close to distal margin.

Male genitalia (Figs. 7-8): segment VIII a complete ring; segment IX asymmetrical, with straight lateral processes, inferior appendages fused basally to form a protruding tube with free dorsad and ventrad directed hooks. Phallic apparatus very long, with a short and thin paramere.

Diagnosis: The new species resembles $O$. epupae sp. nov. by the small paramere and the lateral processes of segment IX. The fused inferior appendages and its peculiar apices seem to be a unique character which is diagnostic of the new species.

\section{Orthotrichia epupae sp. nov.}

Holotype $\widehat{\jmath}$, Namibia, Kunene River, Epupa Falls, $1^{\circ} 00.127^{\prime} \mathrm{S} 13^{\circ} 14.742 ’ \mathrm{E}, 2-4.9 .2012$, leg. W. Mey, male genitalia slide Mey 04/13 (MfN)

Paratypes: $17 \hat{\partial}$, same data as holotype; $15 \hat{\partial}$, same locality, 21-23.2.2008, leg. W. Mey; $14 \hat{\partial}$, Namibia, Kunene River,

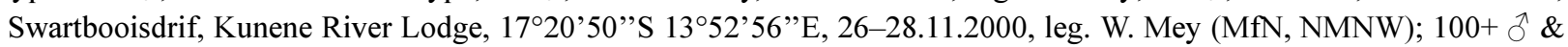

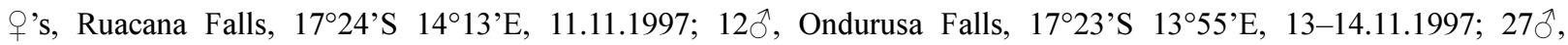
Omapapurawa Guard Post, $17^{\circ} 13^{\prime} \mathrm{S} 13^{\circ} 39^{\prime} \mathrm{E}, 15.11 .1997$; 83 ${ }^{\lambda}, 27$, , Oonjana Camp site, $17^{\circ} 01^{\prime} \mathrm{S} 13^{\circ} 26^{\prime} \mathrm{E}$, 17-

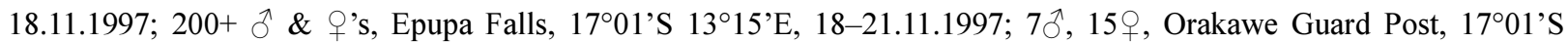

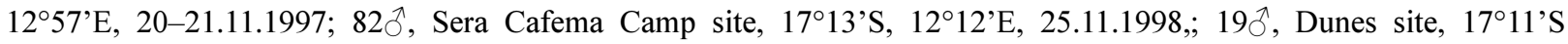
1359’E, 25.11.1998; all leg. F. deMoor, species listed under KUN 74AA (AMG).

Etymology: The specific name is derived from the type locality on the Kunene River, the Epupa Falls.

Description. Adult: Length of forewing 1.9-2.0 mm, wing-span 4.8-5.0 mm. Head with grey-brown hairs on frons and vertex, and white hairs mixed with grey on occipital region; antenna white, female antenna white, with dark apical segments; forewings brown, white spots on wing margin, anal field brown; underside of costal vein with a short row of black, androconial scales. Venter of segment VIII with median process.

Male genitalia (Figs. 9-11): Tergum and sternum of segment IX separate, sternum with two, asymmetrical, posterolateral appendages, bearing long spines at apex; right appendage bifid; inferior appendages plate-like, with tips ending in a curved hook, tergum $\mathrm{X}$ with a recurved hook on dorsal side and a long, undulating, spiny process. Phallic apparatus with small paramere, not turned around shaft.

Diagnosis: The male genitalia show resemblance to $O$. moselyi Tjeder, 1946 from Yemen. The new species differs by the small paramere of the phallic apparatus, the shape of the inferior appendages and the recurved, dorsal teeth of segment IX.

Orthotrichia vadalis sp. nov.

Holotype ${ }^{\lambda}$, Namibia, Kunene River, Epupa Falls, $17^{\circ} 00^{\prime} 24^{\prime \prime}$ S $13^{\circ} 14^{\prime} 52^{\prime \prime} \mathrm{E}, 2-4.9 .2012$, at the lights, leg. W. Mey, male genitalia slide Mey 05/13 (MfN)

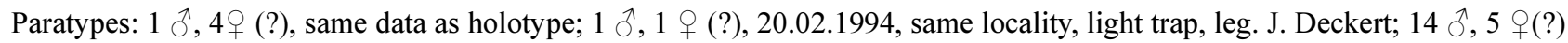
Namibia, Kunene River, Swartbooisdrif, Kunene River Lodge, 17²0’50”'S 1352’56”E, 26-28.11.2000, leg. W. Mey (all MfN). ); $1 \partial^{\Uparrow}$, Sera Cafema Camp site, $17^{\circ} 13^{\prime} \mathrm{S}, 12^{\circ} 12^{\prime} \mathrm{E}, 25.11 .1998$, and additional specimens, leg. F. de Moor, species listed under KUN 116I (AMG).

Etymology: The specific name is derived from vadum (Latin), ford, referring to the ford crossing the river on Swartbooisdrif.

Description. Adult: Length of forewing 1.7-2.0 mm, wing-span 4.6-5.0 mm. Head with white hairs on frons, vertex, and on occipital region, ocelli absent; antenna white, female antenna white, with dark apical segments; forewings brown, white spots on wing margin, anal field white; underside of costal vein with a short row of black, androconial scales.

Male genitalia (Figs. 12-14): Tergum and sternum of segment IX fused, sternum with two, asymmetrical, posterolateral appendages; right appendage bifid and bent dorsad; inferior appendages triangular, somewhat overlapping and asymmetrical, tips acuminate; tergum $\mathrm{X}$ with a short spine and a club-shaped process on dorsal side. Phallic apparatus with long paramere, winding around shaft. 
Diagnosis: The male genitalia are similar to O. straelenis Jaquemart, 1956 and O. benguelensis Marlier, 1965. The new species differs mainly by the shape of the inferior appendages and the large process on tergum X.
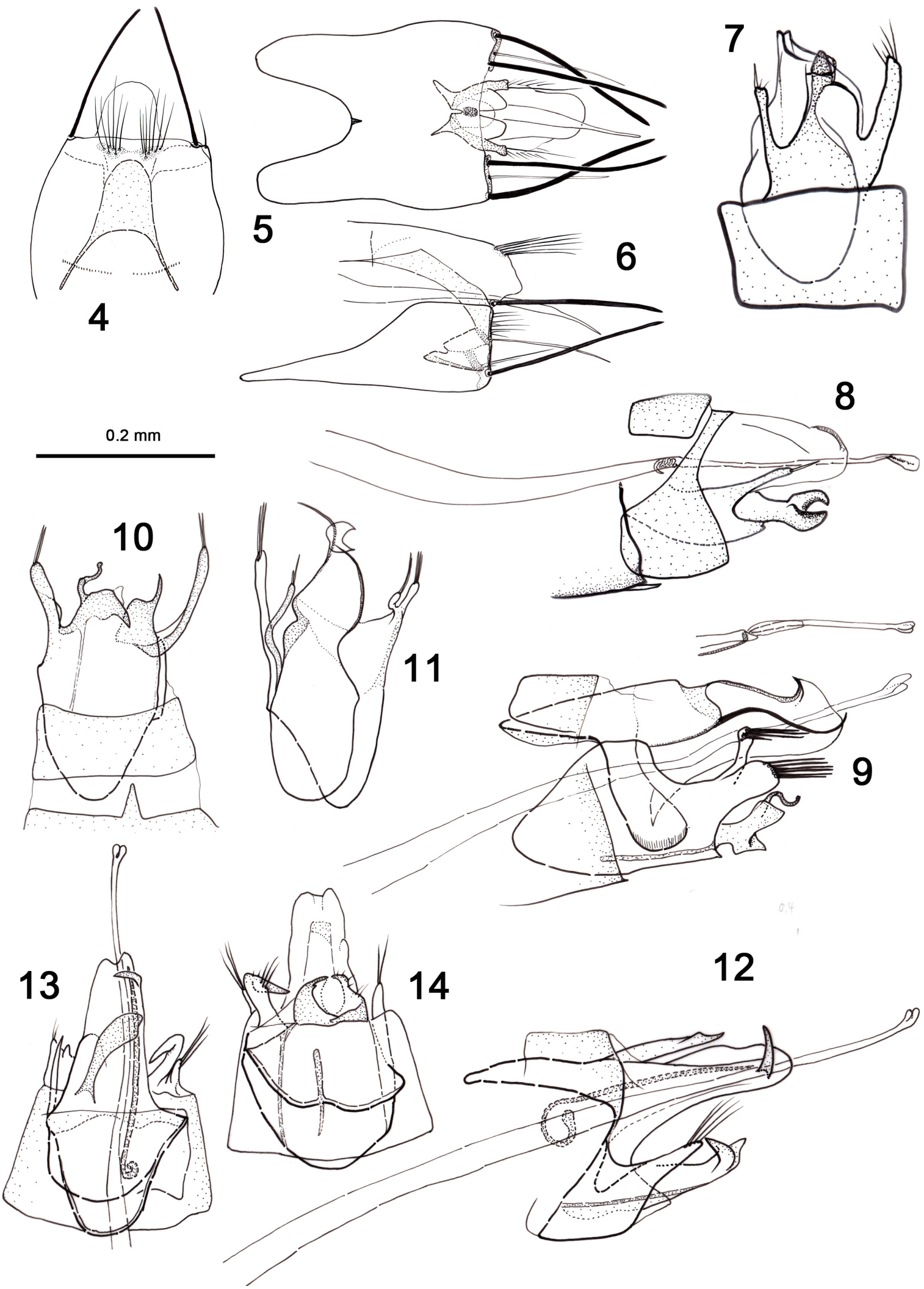

FIGURE 4-14. Catoxyethira kunenica sp. nov., male genitalia, 4-dorsal, 5-ventral, 6-lateral. Orthotrichia kunenensis sp. nov., male genitalia, 7-ventral, 8-lateral. Orthotrichia epupae sp. nov., male genitalia, 9lateral, 10-ventral, 11-dorsal. Orthotrichia vadalis sp. nov., male genitalia, 12- lateral, 13-dorsal, 14-ventral. 


\section{Ecnomidae}

Ecnomus quadrangulatus sp. nov.

Holotype ${ }^{\lambda}$, Namibia, Kunene River, Epupa Falls, 1700'24’S 1314'52’'E ,2-4.9.2012, at the lights, leg. W. Mey, (MfN)

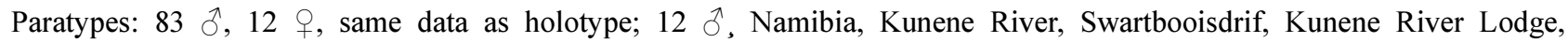

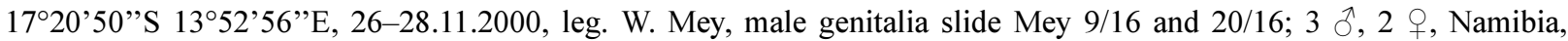

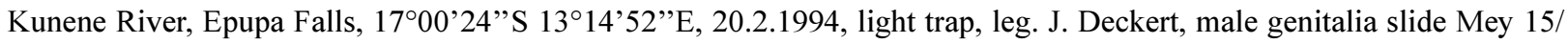

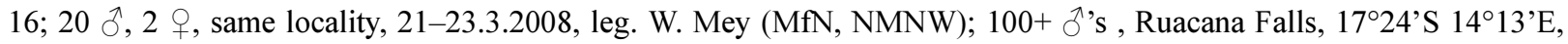

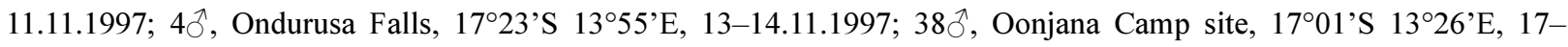

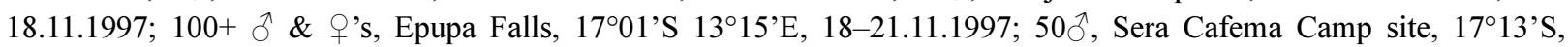

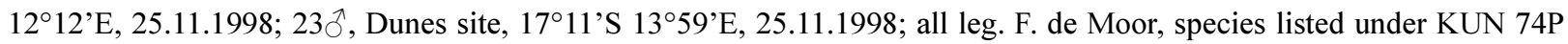
(AMG).

Etymology: The specific epithet refers to the nearly quadrangular shape of the inferior appendages in ventral view.

Description. Adult: Length of forewing 3-4 mm, wing-span 7-8 mm. Head pale grey, setal warts brown, occipital warts with long, brown hairs, hairs on frons and vertex yellow-brown; antennae yellow, with thinly lined articulations. Forewings pale brown, with darker spots on wing margin and a larger spot on pterostigma. Fork 2 sessile, fork 3 shorter than its stalk $(\mathrm{M} 1+2)$.

Male genitalia (Figs. 15-17): Superior appendages sub-rectangular viewed laterally, with a short bifid internal process on median side, and a longer, hook-like appendage; inferior appendages shorter than superior appendages, ventral side sub-rectangular, dorsal margin concave in lateral view; phallic apparatus sinuously bent, apex extending into a beak-like rod curved ventrad.

Diagnosis: The male genitalia of the new species are similar to E. complex Mosely, 1932 and E. similis Mosely, 1932. The main differences are present in the shape of the phallic apparatus and in the form of the inferior appendages, which are not triangular as in the mentioned species. The genitalia of the new species were already illustrated by Jacquemart (1957) under the name E. similis from the Democratic Republic of Congo (wrong identification).

\section{Ecnomus magnus sp. nov.}

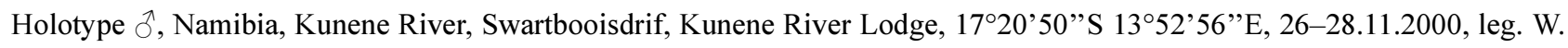
Mey, male genitalia slide Mey 8/16 (MfN)

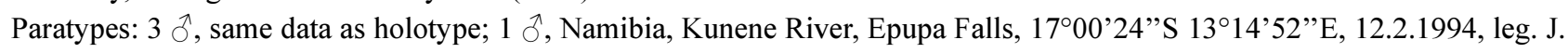

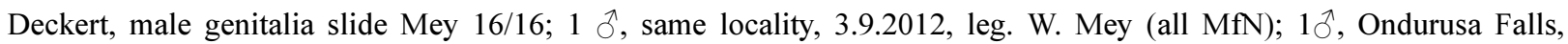
$17^{\circ} 23^{\prime} \mathrm{S} 13^{\circ} 55^{\prime} \mathrm{E}, 13-14.11 .1997$; $1 \mathrm{\delta}^{\lambda}$, Oonjana Camp site, $17^{\circ} 01^{\prime} \mathrm{S} 13^{\circ} 26^{\prime} \mathrm{E}, 17-18.11 .1997 ; 30^{\lambda}$ Epupa Falls, $17^{\circ} 01^{\prime} \mathrm{S}$

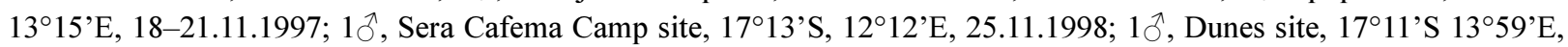
25.11.1998; all leg. F. de Moor, species listed under KUN 74R (AMG).

Etymology: From magnus (Latin), large size, because the species is the largest of all sympatrically occurring Ecnomus species of the Kunene River.

Description. Adult: Length of forewing $5 \mathrm{~mm}$, wing-span 11-13 mm. Head brown, occipital warts darker with long, brown hairs, antennae yellow-brown, with thinly lined articulations. Forewings pale brown, with darker spots on wing margin.

Male genitalia (Figs. 18-20): Superior appendages long, with concave, ventral margins and two internal appendages; inferior appendages slightly shorter than superior appendages, ventral side triangular, with an irregular, dentate margin on median side, dorsal margin concave in lateral view; phallic apparatus sinuously bent, extending apically to form a straight rod.

Diagnosis: The male genitalia of the new species are very similar to E. concavus Kimmins, 1957, described from Uganda. Both species share the dentate inner margin of the inferior appendages in ventral view, but these appendages are longer in E. magnus sp. nov. and not having an oval form in lateral view. The ventral margins of the superior appendages are concave and not straight as in E. concavus. 

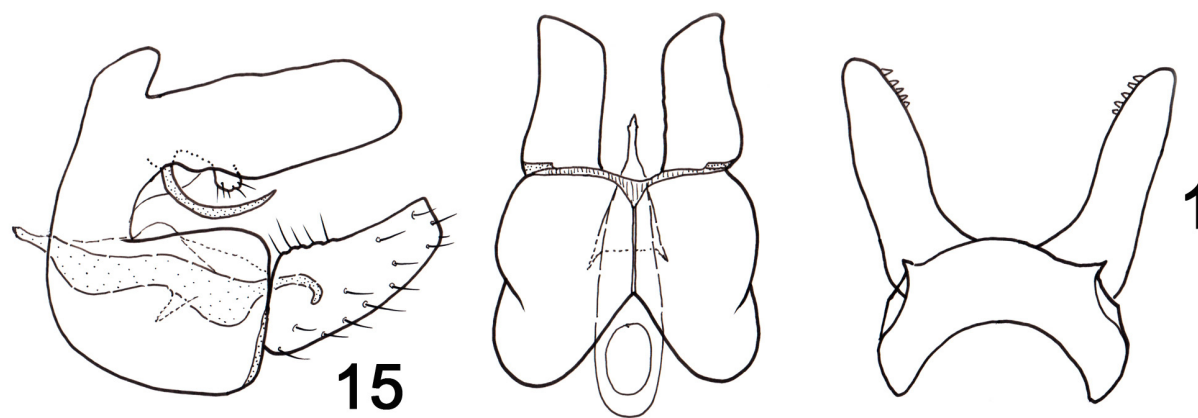

17

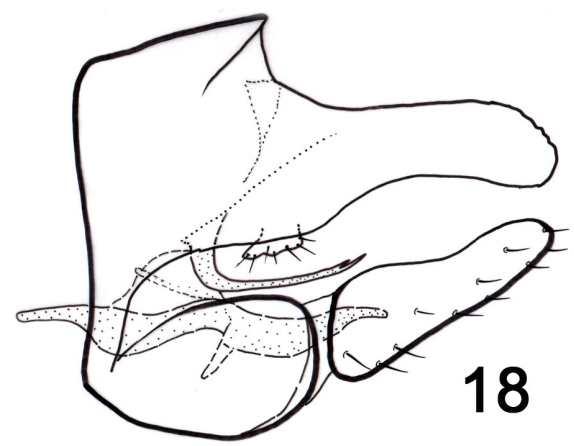

16

22

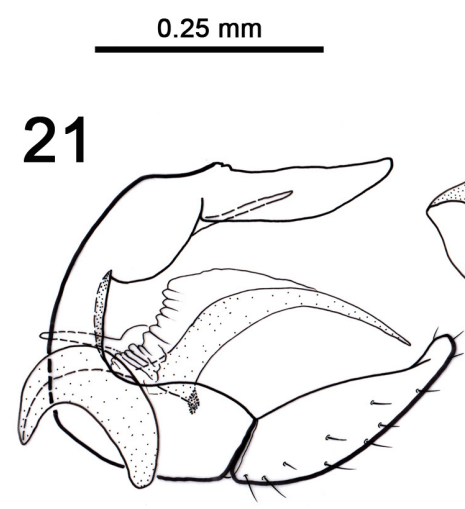

25

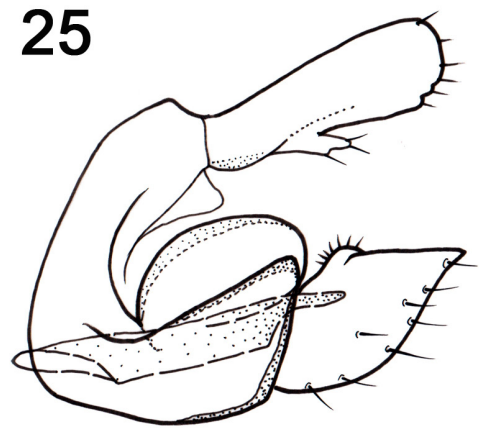

23

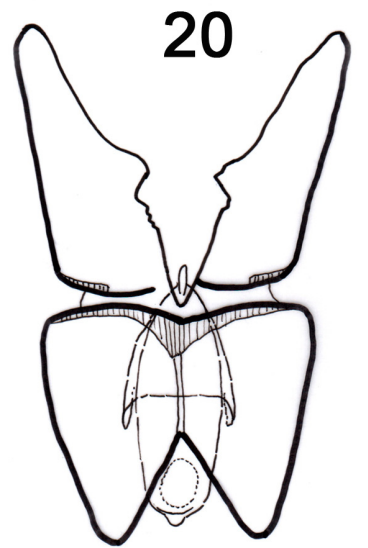

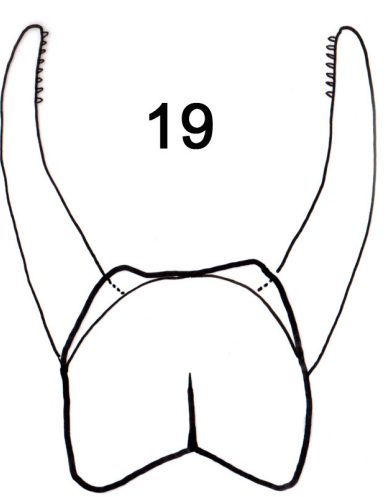

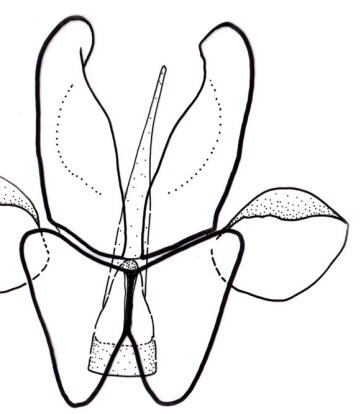

26

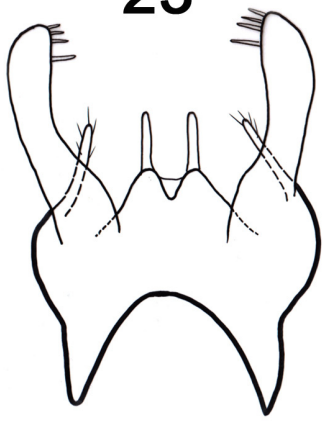

24

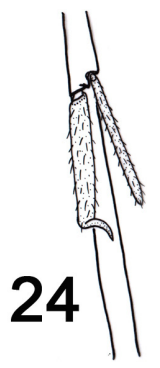

FIGURE 15-27. Ecnomus quadrangulatus sp. nov., male genitalia, 15-lateral, 16-ventral, 17-dorsal. Ecnomus magnus sp. nov., male genitalia, 18-lateral, 19-dorsal, 20-ventral. Ecnomus (Psychomyiellodes) statzneri sp. nov., male genitalia, 21-lateral, 22-ventral, 23-dorsal; 24-modified spurs on male hindtibia. Ecnomus (Psychomyiellodes) angonamus sp. nov., male genitalia, 25-lateral, 26-ventral, 27-dorsal. 
Ecnomus (Psychomyiellodes) statzneri sp. nov.

Holotype $0^{\Uparrow}$, Namibia, Kunene River, Epupa Falls, 1700'24”S 1314'52’'E, 2-4.9.2012, leg. W. Mey, (MfN)

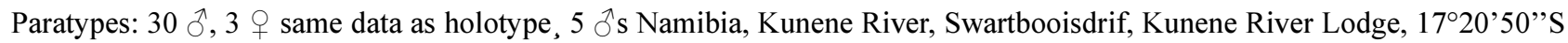

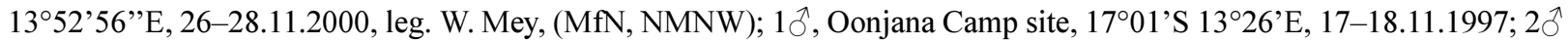
Epupa Falls, $17^{\circ} 01^{\prime} \mathrm{S} 13^{\circ} 15^{\prime} \mathrm{E}, 18-21.11 .1997$; all leg. F. de Moor, species listed under KUN 74S (AMG).

Etymology: The species is named in honour of B. Statzner, who donated his Trichoptera collection to the Museum für Naturkunde, Berlin in 2001.

Description. Adult: Length of forewing 3.0-3.5 mm. Head and thorax brown; hairs on frons yellowbrown and darker on occipital warts; antennae yellow, with thin, brown rings on articulations; forewings brown, with paler spots dispersed irregularly; fork 1 and fork 3 stalked in forewing. Inner spur of male hindtibia modified (Fig. 24).

Male genitalia (Figs. 21-23): Lateral part of segment IX slender, dorsal part with a pair of small processes on the dorso-median margin and a second pair of longer processes on the inner base of superior appendages; superior appendages long and slender, apically rounded and equipped with some short spines on the median side; inferior appendages longer than superior ones, apically rounded and somewhat bent dorso-mediad; lateral projecting lobes large and cup-like; phallic apparatus sickle-shaped, dorsal side membranous.,

Diagnosis: The new species belongs to the group of species, which were formerly included in the genus Psychomyiellodes Mosely, 1931. The group is defined by the presence of laterally protruding appendages of the phallic apparatus, which might be parameres. Ecnomus statzneri sp. nov. is obviously closely related to $E$. spinifer Jacquemart and Statzner, 1981, described from the Democratic Republic of Congo. A comparison of type material of E. spinifer and specimens from the Kunene revealed constant differences in the size of segment IX, in the form of superior appendages and in the shape of the inferior appendages. The modified inner spur of the male hindtibia is, however, nearly identical in both species.

Ecnomus (Psychomyiellodes) angonamus sp. nov.

Holotype đ̋, Namibia, Kunene River, Swartbooisdrif, Kunene River Lodge, 17²0’50”S 1352'56”E, 26-28.11.2000, leg. W. Mey, genitalia slide Mey 10/16 (MfN)

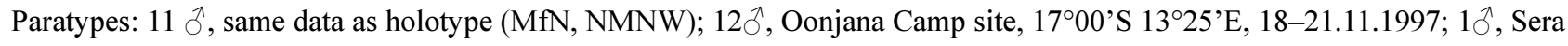
Cafema Camp site, $17^{\circ} 13$ 'S, $12^{\circ} 12^{\prime} \mathrm{E}, 25.11 .1998$, all leg. F. de Moor, species listed under KUN 74T (AMG).

Etymology: The species name is an artificial adjective composed of the first syllables of the country names of Angola and Namibia.

Description. Adult: Length of forewing 3.0-3.2 mm. Head and thorax brown; hairs on frons yellowbrown and darker on occipital warts; antennae yellow, with thin, brown rings on articulations; forewings brown, with paler spots dispersed irregularly on the wing area.

Male genitalia (Figs. 25-27): Superior appendages diverging in dorsal view, club-shaped in lateral view, with a small internal process; inferior appendages short, distal corners with acuminate extensions; phallic apparatus straight, lateral prolongations small and cup-like.

Diagnosis: The new species also belongs to the species group previously placed in Psychomyiellodes. The new species is close to E. dendatus Kimmins, 1957. The main differences are found in the apical margin of the inferior appendages which have long and pointed extensions on the inner, ventral corner.

\section{Hydropsychidae}

Aethaloptera dispar Brauer, 1875

Material examined: 12 ๙े, Namibia, Kunene River, Swartbooisdrif, Kunene River Lodge, 17²0'50"S

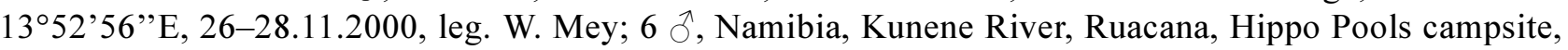
$17^{\circ} 24^{\prime}$ 'S $14^{\circ} 13^{\prime} \mathrm{E}$, light trap, 22.2.2008, leg. J. Deckert \& P. Schönefeld (all MfN). 

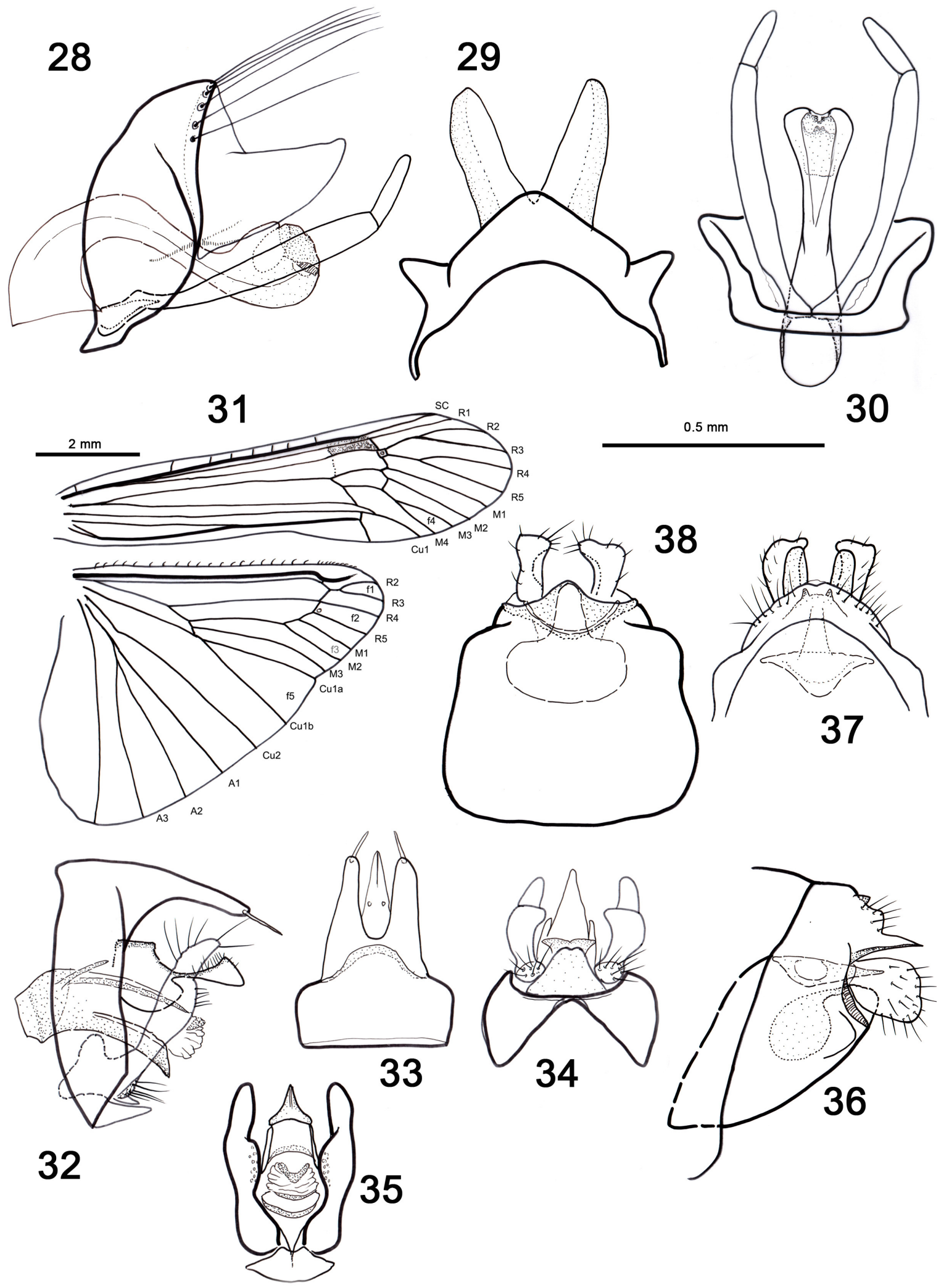

FIGURE 28-38. Aethaloptera dispar Brauer, 1875, male genitalia, 28-lateral, 29-dorsal, 30-ventral; male wing venation. Ceraclea (Pseudoleptocerus) lepidopterella sp. nov., male genitalia, 32-lateral, 33-dorsal, 34ventral, 35-caudal. Oecetis kunenensis Barnard, 1934, female genitalia, 36-lateral, 37-dorsal, 38-ventral. 
Remarks: In Namibia the genus Aethaloptera is represented by two species: A. maxima Ulmer, 1906 and A. dispar (Brauer, 1875). Both occur on the rivers of the Caprivi Strip and only the former is found along the Orange River (Mey 2011). The Aethaloptera specimens of the Kunene are determined as A. dispar, but differ in wing venation and male genitalia from the illustrations given by Barnard (1980). The species is variable throughout its large range from West to South Africa. Further studies must show whether it is merely a polymorphic species or represents a complex of cryptic species. Wing venation and male genitalia of Kunene specimens are depicted in Figs. 28-31.

\section{Leptoceridae}

Ceraclea (Pseudoleptocerus) lepidopterella sp. nov.

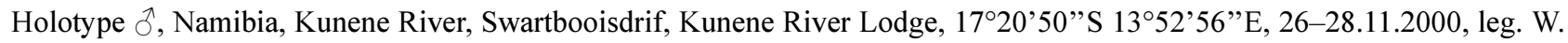
Mey, (MfN)

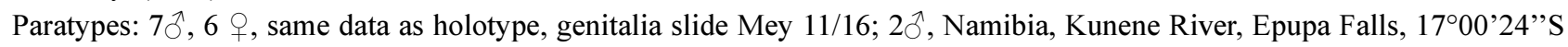

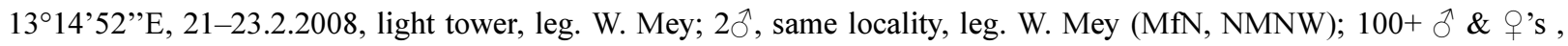

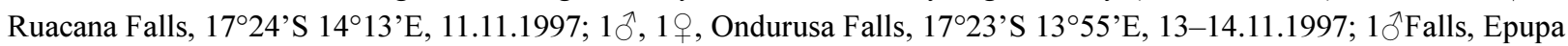
Falls, $17^{\circ} 01^{\prime} \mathrm{S} 13^{\circ} 15^{\prime} \mathrm{E}, 18-21.11 .1997$, all leg. F. de Moor, species listed under KUN 83H (AMG).

Etymology: The species is named after the scales on the forewings forming a colourful wing pattern as in Lepidoptera species.

Description. Adult: Length of forewing 6.9-7.5 mm. Males larger than females. Head and thorax dark brown with white hairs; hairs on palpi white; antennae dark brown, with white bands on articulations of first 15 segments; forewings with red-orange fasciae of scales, interrupted by white or translucent bands, a large white, triangular spot present on pterostigma; fork 1 stalked in forewing; tarsal segments brown, white on basal articulations.

Male genitalia (Figs. 32-35): Dorsum of segment IX with two long processes equipped with a single spine on each apex, ventral process broad and bifid at distal margin; segment $\mathrm{X}$ undivided and triangular in dorsal view, apex in form of a triangular plate on a slender stalk in lateral view; inferior appendages upright, excavated at the base on median sides; phallic apparatus with two pairs of parameres and a large phallotremal sclerite.

Diagnosis: Species of Ceraclea Stephens, 1829, subgenus Pseudoleptocerus Ulmer, 1907 are outstanding caddisflies because of their colourful forewing pattern which is formed by scales. Pinned specimens can be identified by this pattern, which however, disappears largely when the insect is preserved in alcohol. The Pseudoleptocerus material collected on the Kunene clearly belongs to two different species. Barnard (1934) described P. cupreus from this river. This species has a blue fascia on the forewings, which is replaced by redorange fascia in the second species which was unknown and is described herein. The new species also differs from its congeners by the male genitalia, which has a triangular and acute tip of segment $X$ in lateral view. Interestingly, Barnard (1934) recorded a single male of $P$. cupreus also from Clanwilliam, about $2000 \mathrm{~km}$ further south, in the Western Cape. He considered the specimen to be an infraspecific variation and named it var. subfuscus Barnard, 1934.

Oecetis kunenensis Barnard, 1934

= Oecetis reticulatella Kimmins, 1957, syn. nov.

Material examined: $10{ }^{\Uparrow}, 18$ + , Namibia, Kunene River, Swartbooisdrif, Kunene River Lodge, 17²0'50"S

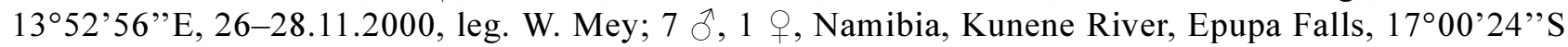
$13^{\circ} 14^{\prime} 52^{\prime \prime}$ E, 2-4.9.2012, light tower, leg. W. Mey; 4 ${ }^{\lambda}, 3$ ㅇ, Namibia, Okarohomba Camp, S $17^{\circ} 15$ E $12^{\circ} 35^{\prime}$, 22-23.2.2015, leg. F. Koch (MfN); several ${ }^{\lambda}$, Ondurusa Falls, Oonjana Camp site and Cafema Camp site, all leg. F. de Moor (AMG); species listed under Oecetis reticulatella in de Moor et al. (2000).

Remarks: Oecetis kunenensis Barnard, 1934 was described from a single female collected on the Kunene River. It was never recorded since. Though the original illustrations of the female genitalia and wing venation are rather simple and not very detailed they nonetheless proved to be useful in recognising the species. In the 
forewings, the presence of a long crossvein between $\mathrm{Cu} 1$ and $\mathrm{Cu} 2$ near the arculus is a rare character in Oecetis. We found this character present in only one species of the several Oecetis species occurring sympatrically on the Kunene. The species was identified by de Moor et al. (2000) as O. reticulatella Kimmins, 1957. The determination was based on the associated males. The examination of the female genitalia provided a good correspondence with the original illustrations of Barnard (1934). Figs. 36-38 give a new illustration of the female genitalia. In comparing the figures of the females and taking into account the wing venation, we conclude, that both names were applied to one and the same species, with $O$. kunenensis as the older, and thus, valid name.

Oecetis tripunctata (Fabricius, 1793)

= Oecetis ovamboensis Barnard, 1934, syn. nov.

Material examined: 32, 19 , Namibia, Kunene River, Swartbooisdrif, Kunene River Lodge, 17²0'50"S 135'ㄷ', 26-28.11.2000, leg. W. Mey (MfN).

Remarks: The original description of $O$. ovamboensis is also based on a single female specimen. In contrast to $O$. kunenensis, the species is of smaller size, has pointed apices in both wings and darkened crossveins in the forewings. This combination of traits together with the morphology of female genitalia is typical of $O$. tripunctata and related species. Oecetis tripunctata occurs on the Kunene sympatrically with the similar O. rama Mosely, 1948. Both species can be separated externally by the forewing venation, where $\mathrm{r}-\mathrm{m}$ and the nygma in the third apical cell take a different position. Only the venation of $O$. tripunctata corresponds with the original forewing figure of $O$. owamboensis. In the absence of any further, similar species, we consider $O$. owamboensis to be a junior synonym of $O$. tripunctata. The species was recently reported from Nosy Bé, Madagascar by Malicky (2015). It seems to be absent in South Africa (cf. de Moor \& Scott 2003).

\section{Acknowledgements}

The colleagues of the first author from the Museum für Naturkunde, J. Deckert, Frank Koch and M. Uhlig collected caddisflies for him at various localities in different years on the banks of the lower Kunene River in Namibia. S. Naumann provided Trichoptera samples from the river in Angola. Their contribution and help deserve the first author's sincere thanks. Financial support for field work was received by the DFG (Me 1085/ 16-01). The second author would like to thank all the people and organisations involved in organising and helping collect material during the two surveys conducted in 1997 and 1998 and these are acknowledged in de Moor et al. (2000). The Directorate of Museums and Heritage, Eastern Cape, are thanked for providing research facilities and encouraging this research.

Thanks are also due to R. Holzenthal, D. Ruiter and Patina K Mendez for reviewing the manuscript

\section{References}

Barnard, K.H. (1934) South African caddis-flies (Trichoptera). Transactions of the Royal Society of South Africa, 21, $291-394$. https://doi.org/10.1080/00359193409518885

Barnard, P.C. (1980) A revision of the Old World Polymorphanisini (Trichoptera: Hydropsychidae). Bulletin of the British Museum (Natural History), Entomology series, 41 (2), 59-106. Available from: https://www.biodiversitylibrary.org/part/ 28547 (accessed 15 March 2019)

Barnard, P. (1998) Biological diversity in Namibia: a country study. Namibian National Biodiversity Task Force, Windhoek.

Cambray, J.A., Davies, B.R. \& Ashton, P.J. (1986) The Orange-Vaal River system. In: Davies B.R \& Walker K.F. (Eds.) The ecology of river systems. Dr W Junk Publishers, Dordrecht, 89-122. https://doi.org/10.1002/iroh.19870720314

Curtis, B.A. (1991) Freshwater macro-invertebrates of Namibia. Madoqua, 17, 163-187.

de Moor, F.C. \& Car, M. (1986) A field evaluation of Bacillus thuringensis var. israelensis as a biological control agent for Simulium chutteri (Diptera: Nematocera) in the Middle Orange River. Onderstepoort Journal of Veterinary Research, 53, 43-50.

de Moor, F.C., Barber-James, H.M., Harrison, A.D. \& Lugo-Ortiz, C.R. (2000) The macroinvertebrates of the Cunene River from the Ruacana Falls to the river mouth and assessment of the conservation status of the river. African Journal of 
Aquatic Science, 25, 105-122.

https://doi.org/10.2989/160859100780177857

de Moor, F.C. \& Scott, K.M.F. (2003) Trichoptera. In: de Moor, I.J., Day, J.A. \& de Moor, F.C. (Eds.): Guides to the Freshwater Invertebrates of Southern Africa, vol. 8, Insecta II, 84-181.

https://doi.org/10.2989/ajas.2009.34.2.13.900

Earle, A., Malzbender, D., Turton, A. \& Manzungu, E. (2005) A preliminary basin profile of the Orange/Sequ River. AWIRU, University of Pretoria, $40 \mathrm{pp}$.

Giller, P.S. \& Malmqvist, B. (1998) The biology of streams and rivers. Oxford University Press, VIII+ 296 pp. https://doi.org/10.1016/s0006-3207(99)00106-8

Harrison, T.D. (1997) A preliminary survey of coastal river systems on the south African west coast, Orange River - Groot Berg, with particular reference to the fish fauna. Transactions of the Royal Society of South Africa, 52, $277-321$. https://doi.org/10.1080/00359199809520356

Hay, C.J., Van Zyl, B.J., Van der Bank, F.H., Ferreira, J.T. \& Steyn, G.J. (1997) A survey of the fishes of the Kunene River, Namibia. Madoqua 19, 129-141.

Hogan, C. (2012) Kunene River. Available from: http://www.eoearth.org/view/article/174385 (accessed 15 March 2019)

Hogan, C. (2013) Orange River. Available from: http://www.eoearth.org/view/article/51 cbfa457896bb431f6bce7b (accessed 15 March 2019)

Jacquemart, S. (1957) Trichoptera des Lacs Kivu et Edouard. Exploration Hydrobiologique des Lacs Kivu, Edouard et Albert (1952-1954), Résultats Scientifiques, 3 (2), 65-129.

Jacquemart, S. \& Statzner, B. (1981) Trichoptères nouveaux de Zaire. Bulletin de l'Institute royale de Societé Naturelle de Belgique (Ent.), 53, 1-25.

Kingsford, R. (2006) Ecology of Desert Rivers. Cambridge University Press, XIII+354 pp.

Magguran, A.E. (2004) Measuring Biological Diversity, $2^{\text {nd }}$ edition. Blackwell Publishing, Oxford.

Malicky, H. (2015) Trichopteren von Nosy Bé (Madagaskar): Beschreibungen von neuen Arten und Kommentare zu bekannten. Braueria (Lunz am See, Austria), 42, 41-49.

Marlier, G. (1962) Genera des Trichoptères de l’Afrique. Annales de Musée Royal de l'Afrique centrale, Tervuren, 109, 263 pp.

Mey, W. (2001) Observations on the caddisfly fauna (Insecta: Trichoptera) of three perennial rivers in northern Namibia. Cimbebasia, 17, 229-236.

Mey, W. (2011) Observations on the caddisfly fauna (Insecta, Trichoptera) of the lower Orange and Fish Rivers in southern Africa with the description of a new species. Zoosymposia, 5, 338-349.

Mey, W. (2016) A case study on the Trichoptera fauna of springs in the escarpment mountains of southern Africa (Insecta, Trichoptera). Zoosymposia, 10, 301-311. http://dx.doi.org/10.11646/zoosymposia.10.1.28

Palmer, R.W. (1996) Invertebrates in the Orange River, with emphasis on conservation and management. South African Journal of aquatic Sciences, 22, 3-51. https://doi.org/10.1080/10183469.1996.9631371

Tobias, D. \& Tobias, W. (updated 2013) Caddisflies of the West Palaearctic and Afrotropical regions of Africa, Working documents. Available from: http://trichoptera.insects-online.de/ (Accessed 13 July 2019)

Simmons, R.E., Braby, R. \& Braby, S.J. (1993) Ecological studies on the Cunene River mouth: avifauna, herpetofauna, water quality, flow rates, geomorphology and implications of the Epupa Dam. Madoqua, 18, 163-180. 